\title{
THE FINANCIAL CRISIS: WHAT IMPACT ON THE ECONOMY AND ON THE FINANCIAL MARKET?
}

\author{
Ammar Samout ${ }^{*}{ }^{凶}$, Amel Raddaoui ${ }^{2}$ \\ ${ }^{1}$ Department of Management Science, Faculty of Economics and Management of Sfax-Tunisia, \\ Tunisia \\ ${ }^{2}$ Researcher in Economics - Sfax-Tunisia University, Tunisia
}

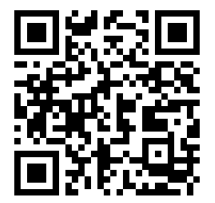

DOI: https://doi.org/10.29121/IJOEST.v4.i5.2020.121

Article Type: Research Article

Article Citation: Ammar Samout, and Amel Raddaoui. (2020). THE FINANCIAL CRISIS: WHAT IMPACT ON THE ECONOMY AND ON THE FINANCIAL MARKET?. International Journal of Engineering Science Technologies, 4(5), 98-107. https://doi.org/10.29121/IJOEST.v 4.i5.2020.121

Received Date: 21 September 2020

Accepted Date: 31 October 2020

Keywords:

Health Crisis

Covid-19

\section{ABSTRACT}

In this article we are interested in a current issue, namely to what extent and by what mechanisms can the COVID-19 health crisis influence the economy and the financial market. This article proposes, after having defined the concepts "the health crisis, economic crisis and financial crisis", to assess the impact of the health crisis on the economy and on the financial market.

To answer this question, we have opted for a methodology that consists of reviewing the theoretical literature on the subject first, and then going on to a study of the socio-economic and financial impact of COVID19.

\section{INTRODUCTION}

The COVID 19 health crisis has become, nowadays, one of the phrases most used by all, although it is not understood by others. The health crisis, coupled with the global economic and financial crisis, has been on everyone's lips since the start of 2020, a topical subject.

In all major regions of the world, the economic recession is deep, leading to unemployment, the collapse of state social programs and the impoverishment of millions of people.

Despite the diversity of points of view and perspectives presented by several researchers, they nevertheless arrive, all unanimously, at the same conclusion: humanity finds itself at the crossroads of the most serious health, economic and social crisis of modern history

However, our study differs from these previous studies in that it seeks to demonstrate in a very detailed way the impact of the global health crisis in the areas of everyday life. 


\section{FROM THE HEALTH CRISIS TO THE ECONOMIC CRISIS}

The Covid-19 epidemic started in China at the end of 2019, the economy of this country logically being the first to be affected. The global economy then came to a halt as the virus spread. The world could experience the most violent economic crisis since 1945 due to the Covid-19 pandemic.

The epidemic is having a huge economic impact, especially when countries resort to containment. The crisis is expected to be the most violent since World War II. Indeed, it is not the virus in itself that created the economic crisis, it is the way in which the government conducts its health policy given the state of the medical infrastructure in terms of hospitalization and testing capacity. , and given the number of masks available.

The decision to stop non-essential activities, the climate of fear, and the closure of schools have caused all economic activity to slow down sharply. It is urgent that the government integrate this element and make it a priority to guide businesses, businesses and services towards the resumption of activity with the establishment of the necessary health guarantees. Indeed, this economic crisis of the coronavirus is not only a demand shock like the subprime crisis, it is also a massive supply shock.

In the United States, the unemployment rate jumped to $14.7 \%$ of the labor force in April, compared to $3.6 \%$ at the end of 2019. The exact figure could be closer to $20 \%$ because, due to the large number of Unemployment registrations, the statistical services are struggling to quickly count the exact number of unemployed.

Australia is experiencing a similar, albeit less drastic, development with an unemployment rate expected to hit $10 \%$ in June, according to the central bank. This would represent a doubling from the start of the year.

Many developing countries have received emergency aid from the IMF to deal with the crisis, for example Côte d'Ivoire obtained a loan of 216.8 million SDRs (approximately 257 million euros). About 30 other countries have obtained IMF loans since the outbreak of the pandemic. In the UK, car sales fell 97\% in April 2020 (compared to April 2019). The number of car sales fell back in April to its 1945 level! The French economy is also heavily impacted, for example with a 16.2\% drop in industrial production in March (compared to February). In Saudi Arabia, the fall in the price of oil and the paralysis of the economy will lead to a widening of the public deficit. That is why the government is considering tripling the VAT from $5 \%$ to $15 \%$. However, this increase could harm consumption and therefore slow down the economic recovery.

\section{SOCIOECONOMIC AND FINANCIAL IMPACT OF THE HEALTH CRISIS}

The current financial crisis is attracting special attention from all economists and in particular from financial crisis theorists. If the 2020 economic crisis follows the same logic as the historical precedents, then the global health consequences could be significant.

Potentially, tens of thousands of suicides, hundreds of thousands of premature deaths from cancer or other chronic diseases are to be expected. Not to mention an invisible health record: that of the slow deterioration in the health of vulnerable populations.

\subsection{IMPACT ON THE NATIONAL ECONOMY}

The covid-19 crisis has had a direct impact on the Tunisian economy and in particular on Tunisian companies, some of which have been severely impacted.

Since March 02, 2020, when the coronavirus first appeared in Tunisia, the health situation has become more and more critical. Indeed, the number of infected is growing remarkably every day knowing that the government and medical staff are making great efforts to face this unexpected health crisis. On March 28, 2020, the number of infected with this virus reached 278 among which nine citizens died. In Europe and the United States, the spread of the coronavirus is developing dramatically, which has led several countries to close their borders and stop all types of transactions.

The Ministry of Development, Investment and International Cooperation presented, on Wednesday, June 17, the results of a new study on the economic impact of the Covid-19 pandemic in Tunisia developed in partnership with the UNDP. The results of this study were announced at a press conference this morning at the headquarters of the Ministry of Investment. 
The COVID-19 pandemic would lead to economic growth of $-4.4 \%$ in 2020 , compared with growth initially planned under the 2020 finance law, of $2.7 \%$, under the influence of several factors: (1) a supply shock the impact of which is direct and negative on the activity of several sectors; (2) a reduction in household demand due to the confinement and the drop in income for many of them.

The main components of aggregate demand are also expected to decline in 2020: $-4.9 \%$ for overall investment, $-8 \%$ for household consumption, $-8 \%$ for exports. On the supply side, imports should also fall by $-9.6 \%$.

The containment and drop in production would also lead to an increase in the unemployment rate estimated at $21.6 \%$ against $15 \%$ currently, or nearly 274,500 new unemployed in 2020.

The number of jobs temporarily lost due to the crisis is estimated at 143,000 jobs. And this for a period of one month and 430,000 for three months of confinement. According to a study developed in collaboration with the International Food Policy Research Institute (IFPRI), the income of Tunisian households will decline on average. This is $2.9 \%$ for the duration of one month of the crisis and $8.6 \%$ for three months.

"Greater absolute income losses are observed for households in urban areas of Tunisia. While the impacts for households involved in agriculture, and other components of the food system, have been less severe. Except for households whose members work in other economic sectors, "the study finds.

The Tunisian economy is very open to the rest of the world, and therefore very vulnerable to exogenous shocks. However, according to the IMF, the Covid-19 crisis would cause a contraction of the world economy of around 3\% in 2020. The Tunisian economy depends in particular largely on those of its European partners with whom it achieves $65 \%$ of its imports and $70 \%$ of its exports. However, exports and imports fell respectively by $29.5 \%$ and $29.2 \%$ in March 2020 compared to the same month of 2019. Given the dependency ratio (measured by the ratio of imports to the sum of the production and imports net of exports) by $60 \%$ in 2019 , the contraction in foreign trade observed in March would therefore cost 1.5 points of growth. Without being too pessimistic, it is possible to hypothesize that the crisis will hit April [1] and May with equal intensity before stabilizing in June. Under these conditions the result will be a depression of 4.5 points by the end of 2020 .

The Covid-19 crisis is simultaneously a crisis of supply and demand. Data on the development of the growth rate for the first quarter of 2020 published by the National Institute of Statistics shows a recession of $1.7 \%$ of GDP

Table 1 below summarizes the results of the general equilibrium estimates of the impact of COVID-19 on the main macroeconomic aggregates.

The COVID-19 pandemic would lead to economic growth of $-4.4 \%$, compared to growth initially planned under the 2020 finance law, of $2.7 \%$.

Several factors would be at the origin of this decline in growth for the year 2020: (1) a negative supply shock, the impact of which is direct on the activity of several sectors. All other things being equal, this shock is transmitted to other sectors causing indirect effects through a drop in demand addressed to these sectors as intermediate consumption, (2) a reduction in household consumption due to the confinement and drop in income for a large number of them, (3) a reduction in external demand for certain exporting sectors due to the fact that the COVID-19 pandemic has also impacted Tunisia's main trading partners. The combination of these different effects would result in an increase in the consumer price index (CPI). Indeed, the impact on prices depends on the magnitude of the supply and demand shocks. If the supply shock is more (less) than the demand shock, the price of a given product / service increases (decreases).

Table 1: Impact of the health crisis on Tunisian macroeconomic aggregates

\begin{tabular}{|c|c|c|}
\hline & Baseline scenario & Covid-19 crisis scenario \\
\hline Gross domestic product & 2,7 & $-4,4$ \\
\hline Inflation rate (CPI) & 6,7 & 7,0 \\
\hline Unemployment rate & 15,0 & 21,6 \\
\hline Gross Fixed Capital Formation & 2,9 & $-4,9$ \\
\hline Household consumption & 1,9 & $-8,0$ \\
\hline Exports & 5,8 & $-8,0$ \\
\hline Imports & 3,8 & $-9,6$ \\
\hline Indirect taxes & 11,3 & 1,5 \\
\hline Personal income taxes & 9,5 & 1,4 \\
\hline Society taxes & 4,6 & $-6,0$ \\
\hline
\end{tabular}

Source: Authors' calculations based on estimates from the CGE model and data from the 2020 finance law. 
The overall effect of COVID-19 would therefore be negative on the Tunisian economy for the year 2020, with a decline in growth of $-4.4 \%$. This fall would be justified mainly by the fall in investments $(-4.9 \%)$, private consumption $(-8 \%)$ and exports $(-8 \%)$, in percentage points compared to the reference scenario.

\subsection{IMPACT OF HEALTH CRISIS ON BUSINESS SECTORS}

The sectors of activity most affected by the crisis are non-manufacturing industries (-29\% on turnover), tourism $(-23 \%$ on turnover), transport $(-19.6 \%$ on turnover) and textiles $(-17.7 \%$ on turnover). The other sectors of activity are also affected, but to a lesser extent. The agrifood industry sector, or even education, are among the least impacted sectors.

The simulations show that the shock of Covid-19 accentuates the financial fragility of the majority of microenterprises, in particular those operating in the transport and storage, accommodation and catering sectors or in the textile, clothing, leather and other sectors. shoes.

Simulations of the impact of Covid-19 on financial vulnerability show strong regional disparities but differentiated by sector of activity. The most affected regions are those of the Center-East, Greater Tunis, the NorthEast and the North-West. The most impacted MTPEs in the textile, clothing, leather and footwear sector are located in the North-East. The most impacted MTPEs in the accommodation and catering sector are located in the SouthWest and the North-West

All sectors except agriculture and fisheries as well as non-market services recorded negative growth rates in value added.

According to a study conducted by the Tunisian Hotel Federation, the sector's contribution to GDP is $14 \%$. Two thirds of this contribution would be wiped out by the crisis, or 221.5 million euros and 300,000 jobs. For the nonmanufacturing industry, mines and Buildings and Public Works were the most affected with $-21 \%$ and $-9.5 \%$ respectively. As for the manufacturing industry, a strong recession affected ceramic and glass building materials ($12 \%)$, textiles, clothing and leather $(-10 \%)$.

The industrial sector will be the hardest hit by the crisis (Figure 1 and Table 1). With production impacted at $52.7 \%$, followed closely by services $(-49.0 \%)$ and agriculture (-16.2\%). And this, according to an evaluation study entitled "The impact of COVID-19 on Tunisia, economy, agrifood system and households". It is carried out by the Tunisian Institute for Competitiveness and Quantitative Studies (ITCEQ).

Table 2: Impact of COVID-19 on the Tunisian agrifood system, percentage change in annual GDP by duration of crisis

\begin{tabular}{|c|c|c|c|c|}
\hline Crisis period & Total & Agriculture & Traitement & Services \\
\hline 1st month & -2.5 & -1.3 & -1.1 & -6.6 \\
\hline 2nd month & -5.0 & -2.7 & -2.2 & -13.4 \\
\hline 3rd month & -7.5 & -4.0 & -3.4 & -20.1 \\
\hline
\end{tabular}

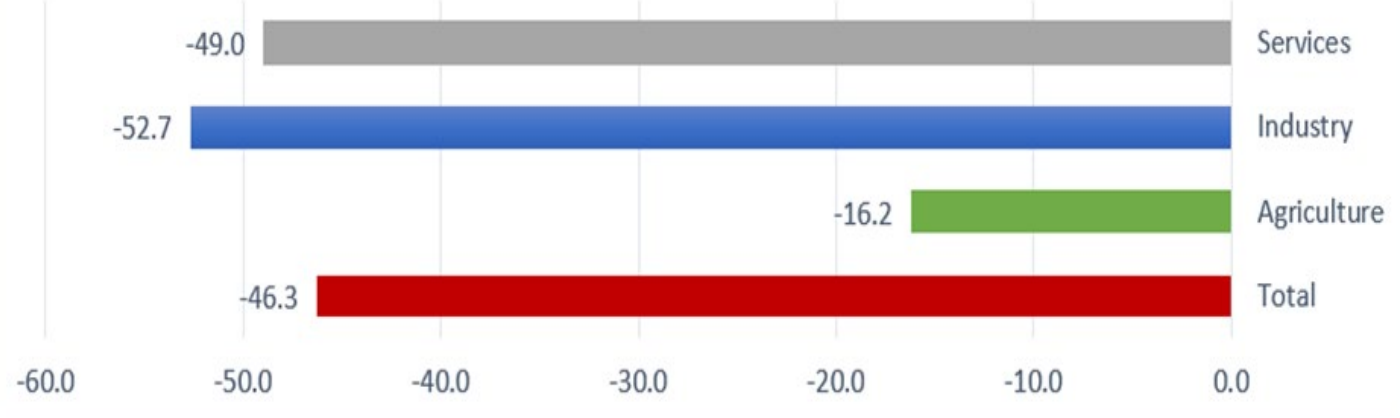

Figure 1: Estimated losses of GDP during the 2nd quarter of 2020 (in percentage)

Source: COVID-19 Tunisia multiply model

The COVID-19 pandemic appears to impact industries in different ways. Table 3 shows the impact on turnover (CA), value added (VA) and gross operating surplus (EBITDA) of the 16 business sectors. 
The hotel and catering industry, transport and textiles, clothing, leather are among the sectors most affected by the COVID-19 crisis because they are the most exposed to containment measures imposed by the Tunisian authorities and therefore to shocks to the both supply and demand.

Other sectors are indirectly impacted, due to their strong connection to the three sectors mentioned above. Agricultural and agrifood products, for example, represent around $85 \%$ of the total intermediate consumption of hotels and restaurants. Consequently, the decrease in the production value of hotels and restaurants by $23 \%$ partly explains the decrease in agricultural and agrifood production by $3 \%$ and $2.8 \%$ respectively.

Table 3: Estimates of the impacts of COVID-19 on sectors of activity (in\%)

\begin{tabular}{|c|c|c|c|c|}
\hline & Employment & Turnover & Added value & Gross operating surplus \\
\hline Agriculture and fishing & $-4,6$ & $-3,0$ & $-4,8$ & $-4,5$ \\
\hline $\begin{array}{c}\text { Non-manufacturing } \\
\text { industries }\end{array}$ & $-34,5$ & $-29,0$ & $-29,4$ & $-25,8$ \\
\hline Agrifoods industries & $-0,1$ & $-2,8$ & $-0,4$ & 1,3 \\
\hline $\begin{array}{l}\text { Textile, Clothing and } \\
\text { Leather }\end{array}$ & $-15,7$ & $-17,7$ & $-14,5$ & $-12,3$ \\
\hline $\begin{array}{l}\text { Woodworking and manufacture of } \\
\text { wooden articles }\end{array}$ & $-4,1$ & $-2,6$ & 0,3 & 4,5 \\
\hline $\begin{array}{c}\text { Metallurgy and Metal } \\
\text { Product Manufacturing }\end{array}$ & $-3,2$ & $-6,9$ & $-3,8$ & $-2,4$ \\
\hline Other industries & $-7,6$ & $-15,1$ & $-9,7$ & $-5,5$ \\
\hline $\begin{array}{l}\text { Building and civil engineering } \\
\text { (construction) }\end{array}$ & 2,6 & $-7,8$ & 2,6 & 4,1 \\
\hline Trade and repair & $-10,0$ & $-10,6$ & $-10,0$ & $-8,4$ \\
\hline Hotels and restaurants & $-15,8$ & $-23,0$ & $-15,8$ & $-14,6$ \\
\hline Transportation & $-15,0$ & $-19,6$ & $-14,1$ & $-10,8$ \\
\hline $\begin{array}{l}\text { Information and } \\
\text { communication }\end{array}$ & $-9,1$ & $-10,2$ & $-10,9$ & $-8,7$ \\
\hline $\begin{array}{c}\text { Other personal } \\
\text { services }\end{array}$ & $-13,0$ & $-12,6$ & $-9,5$ & $-9,4$ \\
\hline Education & $-0,3$ & $-0,6$ & $-0,3$ & $-0,2$ \\
\hline $\begin{array}{l}\text { Human health } \\
\text { activities }\end{array}$ & $-3,4$ & $-4,6$ & $-3,4$ & $-3,1$ \\
\hline Other services & $-1,0$ & $-3,6$ & $-5,4$ & $-1,7$ \\
\hline
\end{tabular}

Source: Authors' estimates based on the CGE model.

Other sectors of activity are also negatively impacted by the COVID-19 crisis, but to a lesser extent. These are, for example, sectors related to other personal services, trade and repair and information and communication. Interestingly, however, the crisis would have a positive effect on the gross operating surplus of the food processing, construction and civil engineering, and woodworking and woodworking industries. Indeed, the fall in the prices of certain products, in particular energy, would lead to a reduction in the cost of intermediate consumption and an increase in added value, despite the fall in the value of production.

\subsection{IMPACT OF THE HEALTH CRISIS ON TUNISIAN SMALL AND MEDIUM ENTERPRISES}

The Tunisian economy had 771,032 companies in $201714.87 .7 \%$ of them have no employees, $7.1 \%$ employ 1 or 2 employees and $2.6 \%$ employ 3 to 5 employees.

SMEs therefore represent $97.3 \%$ of Tunisian companies and employ more than one million people15. This study focused on a field of 455,515 licensed SMEs but considered to be part of the informal sector (see box 1). Indeed, the INS adopts the following definition (recommended by the 2008 SNA) of the informal sector: "The informal sector is 
made up of economic units, whatever their legal status and type of activity (including agriculture)., producing goods and services for the market and not having, in fact or in law, any complete accounting "

The total added value of these microenterprises was estimated at 11,449.9 MTD in 2018, or the equivalent of $10.9 \%$ of GDP. Very few MPTEs are headed by women. These would in fact contribute with an added value of around $1.8 \%$ of GDP.

The distribution of value added by size of MTPE shows a contribution of micro enterprises with less than 2 employees to the tune of $7.3 \%$ of GDP. This contribution is 3\% of the GDP for those employing between 3 to 5 employees 17.

The shock of COVID-19 accentuates the financial fragility of the majority of microenterprises. They also reveal that the most impacted MTPEs are those operating in the sectors of transport and storage, accommodation and catering, textiles, clothing, leather and footwear, information and communication, as well as trade and repair.

\subsection{IMPACT OF THE HEALTH CRISIS ON THE FINANCIAL MARKET}

The Tunisian stock market "BVMT" is adversely affected by the Covid-19 crisis. Indeed, the TUNINDEX capitalization index followed an upward trend throughout the months of January and February 2020 to reach a peak (7204.39 points) on February 28, 2020. However, it fell sharply on March 16, 2020, closing with a value equal to 6116.16 points and registering a decrease equal to $17.8 \%$ between March 02 and March 16. Following the precautionary measures taken by the government such as the imposition of home confinement and the provision of the necessary means to do so, the TUNINDEX index has experienced an uptrend during the last ten days, posting a value equal to 6412,02 points on March 26, 2020, an increase of 4.84\%. Nevertheless, the deterioration of the health situation raises many complex questions for investors and managers

The State and the authorities of the financial sector must therefore intervene to reassure investors by encouraging them to invest in the most profitable assets.

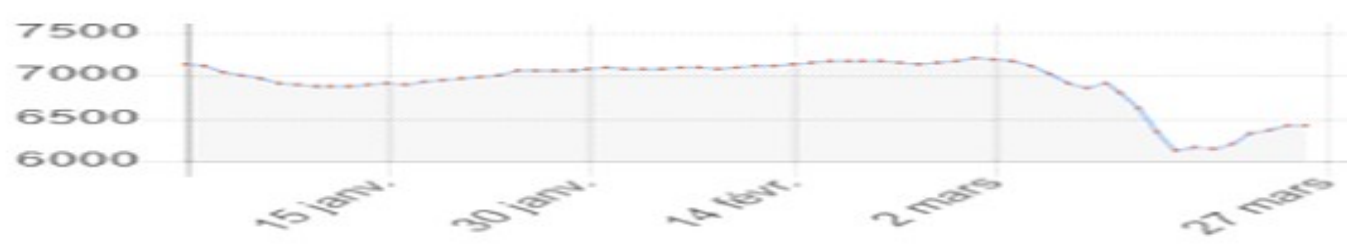

Figure 2: Evolution of the TUNINDEX capitalization index

Source: www.bvmt.com.tn

Of course, the spread of the Covid-19 crisis could lead to a deterioration in the Tunisian economic situation. However, the Tunisian financial system contributes significantly to increasing the level of financial inclusion. Indeed, various measures have been implemented such as: Free bank cards for customers, elimination of withdrawal fees made by cards on ATMs, provision of a wide range of remote banking services allowing customers to perform all day-to-day transactions without going to a branch. Such a measure contributes to the increase of the rate of use of online payment which is not well developed in our country.

Finally, all these measures can substantially enhance the use of financial services, "the main dimension of financial inclusion.

Indeed, the stock markets of several countries showed, until May 13, 2020, declines, like those of Morocco ($22 \%)$, Egypt (-26\%), Saudi Arabia. (-21\%), France (-25\%) and Germany

$(-19 \%)$. 
The Tunis Stock Exchange managed to keep the decline at 10.5\%, thanks to three essential factors.

- First, the sectors that were most immediately affected with the spread of Covid -19 are not represented on the Tunis Stock Exchange, such as the tourism, energy and transport sectors - the latter $\mathrm{n}$ 'being represented only by TUNISAIR. $\varpi$

- The second factor is the investor structure of the Tunis Stock Exchange, made up of a large part of small holders (individuals), who carry out the majority of stock market transactions, while in other countries stock market transactions are carried, essentially, by institutional investors, who tend to sell massively, automatically, when there is a risk, to limit the damage. $\varpi$

- The third factor is the weakness of foreign investors who represent only $25 \%$ of the total market capitalization, of which only $2 \%$ are volatile and $23 \%$ are strategic, long- term. This saved us from great losses, given that foreign investors of a volatile nature, with the spread of the pandemic, withdrew from emerging markets, to fall back to less risky or monetary investments.

\subsection{IMPACT IN TERMS OF MONETARY POVERTY}

The monetary poverty rate would drop to $19.2 \%$ against $15.2 \%$ currently, pushing the incomes of around 475,000 individuals below the monetary poverty line, in the absence of any intervention by the government. the state. Two factors would contribute to this worsening: i) a drop in income per group of households and ii) an increase in the prices of basic foods. The rate of extreme monetary poverty would also increase following the shock of Covid19 , to $3.9 \%$ (against 2.8\% currently).

The COVID-19 pandemic would thus increase the poverty of the poorest categories due to their greater exposure, not only to health risk, but also to socio-economic consequences. The poorest households in Tunisia belong to the socio-professional categories of agricultural and non-agricultural workers, farmers, the unemployed and other inactive. Agricultural workers represent only $2.2 \%$ of the total population but $5.5 \%$ of the population living below the poverty line, or about 2.5 times its demographic weight. The Covid-19 crisis worsens income inequalities, but also inequalities of opportunities in the sense that not all populations have access to the same opportunities for financing, digitization, means of communication, etc.

\section{MAIN MEASURES IMPLEMENTED}

The reopening of the economy and related government support to the sectors may also offer new opportunities for economic transformation.

However, faced with the scale of the effects of COVID-19, the containment measures put in place by the Tunisian government in the context of a fragile macroeconomic situation and with the decline in tax revenues linked to the blocking of activity, the authorities will have to mobilize resources.

The international health crisis caused by Covid-19 has prompted most countries around the world to take preventive measures through containment to prevent the spread of the virus. Tunisia, for its part, has been proactive in taking the necessary health measures by declaring a national state of emergency and adopting containment measures, including total isolation, nighttime curfew, travel bans except repatriation and quarantine of national returnees. The COVID-19 shock comes at a time when Tunisia is already facing persistent macroeconomic imbalances.

Given the scale of the health crisis and the magnitude of its economic effects on a global scale, all countries of the world should work together to reopen trade, tourism and help these countries, like Tunisia, which need it to overcome this unprecedented crisis.

The Tunisian government provided immediate socio-economic responses to limit the impact of the pandemic on vulnerable populations (households and micro-enterprises) as well as more medium-term measures.

\subsection{ECONOMIC MEASURES}

The main measure decided was undoubtedly to lower the key rate of the central bank of Tunisia by 100 basis points. 
The latter rose from $7.75 \%$ to $6.75 \%$, not without the fear that the inflation rate would start to rise again. Inflation which has been on a downward trend for two years but remains high at 5.8\% in February 2020.

The central bank of Tunisia has also decided to postpone for six months, the payment of bank loan maturities for companies.

In this sense, it has expressed its desire to be more lenient with respect to the financial sector by announcing that it will be less careful about the "loan to deposit" ratio, which it has scrupulously called on to be respected by the banks.

Thus, the government and financial institutions must intervene to regulate the financial sector, arbitrate between conflicting interests and above all ensure the long-term survival of these companies. In this context, the board of directors of the Tunisian central bank decided to reduce by 100 basis points the money market rate "TMM" to bring it down to $6.75 \%$ on March 18, 2020 knowing that it reached 7.84\% in February 2020. The graph "1" shows that the evolution of the MMR was practically stable during the period between March 2019 and February 2020 (figure 3). However, this rate decreased considerably in March 2020 following the onset of the health crisis.

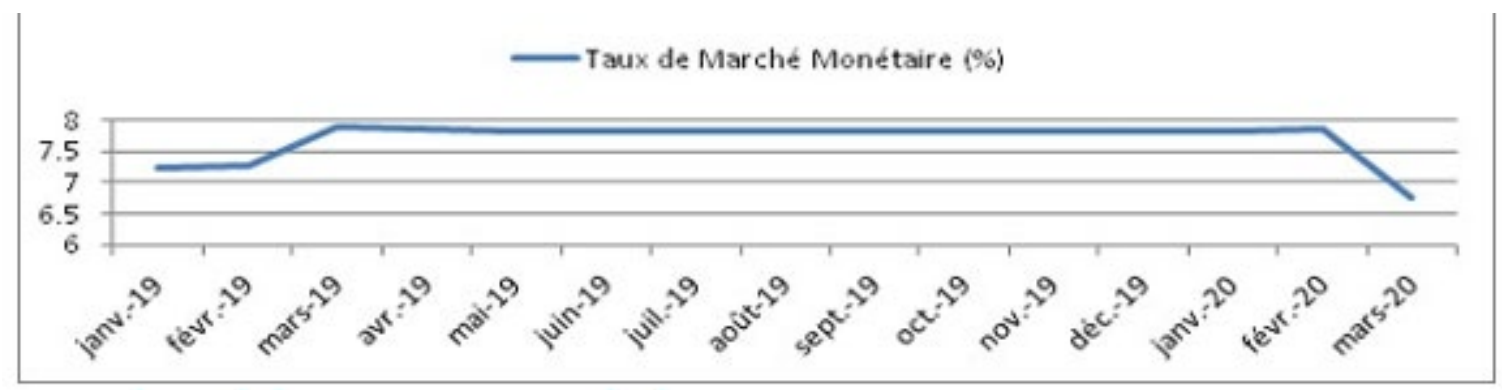

Figure 3: Evolution of the money market rate

Source: Central Bank of Tunisia

\subsection{FINANCIAL MEASURES}

The government is counting on the $\$ 400$ million promised by the IMF to deal with this health crisis. It will also be able to benefit from the profits of the central bank of Tunisia, whose financial statements for the 2019 financial year show a surplus which will bring to the Tunisian treasury some 800 million dinars (275 million dollars).

The government has put in place a variety of measures to support Tunisian companies during the pandemic and to cushion the negative effects of containment. These measures mainly focused on: (i) a guarantee line of 500 MTD, (ii) a financing line of loans to SMEs of 300 MTD

- The interest rate subsidy of 3 points, representing an amount of 40 MTD

- The refund of the tax credit up to 52 MTD

These measures would benefit large and medium-sized businesses that did not have particular difficulties accessing finance before the shock of COVID-19. However, these measures do not contain a window dedicated to financial aid targeting MTPE.

The budgetary allocations mobilized by the State to alleviate the socio-economic damage of Covid-19 amount to 2.5 billion TND, which represents $5.3 \%$ of the 2020 budget. This amount will widen the public finances deficit since the tax revenues of the first quarter of 2020 decreased by $30 \%$ compared to the first quarter of 2019 according to the Ministry of Finance. All the donations deposited by Tunisian citizens and businesses, to the 18-18 postal account, dedicated to the fight against the coronavirus, reached, as of May 6, 2020, 198.3 MD or 8\% of the total envelope provided.

\subsection{SOCIAL MEASURES}

The Central Bank of Tunisia has also imposed a series of exceptional measures aimed at reducing the harmful economic effects of this crisis. In fact, there has been a reduction in financial charges relating to loans taken out by individuals, which contributes to the increase in their purchasing power during this period. There was also an 
injection of liquidity for Tunisian banks. They participated in the creation of a solidarity fund for the medical sector by recently making a donation equal to 112 million dinar.

Although the government has decided to allocate 200 dinars (\$65) for a total amount of 150 million dinars (\$ 51 million) of assistance to needy families, many of whom are active in the informal sector, it seems obvious that the impact on this social layer will be more pronounced.

The government has adopted a set of measures to protect jobs and support households most affected by the shock of COVID-19, in particular vulnerable populations over a period of up to three months. In this regard, an envelope of 950 MTD has been dedicated to support needy families and self-employed workers as well as fragile jobs.

On another level, the government has made considerable efforts to secure the supply of essential products. In this regard, it allocated a budget of 500 MTD to build up strategic stocks of drugs and basic foods. However, in the light of the results of this study, this battery of measures could be insufficient, especially in the event of a second wave of the epidemic.

It is recommended to extend the period of financial support to 6 months for the most vulnerable categories of households. In fact, simulations show that for a confinement lasting three months, the total annual loss of income of the categories of households most affected by the shock of COVID-19 would be 1,830 MTD (which represents approximately double the of the amount allocated by the government). For example, many workers in sectors such as the hotel industry and related industries (crafts, travel agencies, catering, air transport, etc.) will remain unemployed for a long period of time. where the importance of extending the duration of support for these categories of households.

\subsection{SANITARY MEASURES}

In order to minimize the risks of a second wave of the COVID-19 pandemic, it is important to reassure vulnerable households that in the event of contamination, they will benefit from financial support from the State in addition to health care and this in order to encourage them to reveal possible COVID-19 infections. It is important to set up a national standard for compliance with health standards in relation to the COVID-19 pandemic. This standard, coupled with a certification process, would facilitate the generalization of measures to prevent the spread of COVID19 in the workplace.

\section{CONCLUSION}

This is how our work leads us to say that whatever we talk about the causes and factors that triggered the COVID 19 crisis, the most important thing is to try to learn the lessons that will perhaps prevent us from the future another crisis has the magnitude of this crisis. Indeed, this crisis has had painful consequences for the world economy.

As the crisis is global, solutions must logically come from industrialized countries. However, the measures to be taken may vary from one country to another depending on the structure of their economies.

\section{SOURCES OF FUNDING}

This research received no specific grant from any funding agency in the public, commercial, or not-for-profit sectors.

\section{CONFLICT OF INTEREST}

The author have declared that no competing interests exist.

\section{ACKNOWLEDGMENT}

None. 


\section{REFERENCES}

[1] Breisinger, C., M. Thomas, and J. Thurlow. 2009. Social Accounting Matrices and Multiplier Analysis: An Introduction with Exercises. Food Security in Practice Technical Guide no. 5. Washington, D.C.: IFPRI.

[2] Bolivar J.G. (2008). Comment intégrer les questions d'environnement et de développement dans

[3] l'ensemble des méthodologies de la gestion de projet: une démarche conceptuelle orientée vers un modèle de la planification de projet basé sur l'approche cadre logique. Uqar

[4] GENDRON (2004), Développement Durable et Economie Sociale: Convergences et articulations.

[5] IACE (Institut Arabe des Chefs d'Entreprises). 2020. L'impact du covid19 sur les entreprises tunisiennes. Tunis: IACE

[6] Jean Yves Martin, Le développement durable: doctrines pratiques évaluations, (Rapport Brundtland P47), IRD éditions, Paris, 2002, P51

[7] Kamali, A., M. Karara, C. Breisinger, M. Raouf, and M. Wiebelt. forthcoming. COVID-19 and the Egyptian economy: Impact of slowing domestic activity on economic sectors, jobs, and households. MENA Regional Program Policy Note. Cairo: International Food Policy Research Institute.

[8] Koonin, L. M. (2020). Novel coronavirus disease (COVID-19) outbreak: Now is the time to refresh pandemic plans. Journal of Business Continuity \& Emergency Planning, 13(4), 1-15.

[9] Mahler, D.G., C. Lakner, R.A. Castaneda Aguilar, and H. Wu. 2020. The impact of COVID-19 (Coronavirus) on global poverty: Why Sub-Saharan Africa might be the region hardest hit. Washington, DC: International Monetary Fund.

[10] McKibbin, W., \& Fernando, R. (2020). The global macroeconomic impacts of COVID-19: Seven scenarios (No. 2020-19). Centre for Applied Macroeconomic Analysis, Crawford School of Public Policy, The Australian National University.

[11] Notre avenir à tous, Commission mondiale pour l'environnement et le développement, édition du fleuve, publications du Québec, 1987, p.10

[12] Paolo Baracchini, Guide a la mise en place du management environnemental en entreprise selon ISO 14001, 3eme édition, Presses Polytechniques et Universitaires Romandes, 2007, P9

[13] Round, J. 2003. "Social accounting matrices and SAM-based multiplier analysis." In: Techniques and Tools for Evaluating the Poverty Impact of Economic Policies, Bourguignon F. and L. A. Pereira da Silva, eds. Washington, D.C. and Oxford: World Bank and Oxford University Press.

[14] Thurlow, J. 2020. A standard multiplier model for COVID-19 assessments. Unpublished SAM multiplier model (available upon request). Washington, DC: International Food Policy Research Institute.

[15] World Bank. 2020. Tunisia COVID-19 response project. Washington, DC: World Bank. https://projects.worldbank.org/en/projects-operations/project- detail/P173945?lang=en\&tab=overview, accessed April 27, 2020

[16] Banque Centrale de Tunisie

[17] INS (2020)

[18] FMI (2020) 